\title{
Diagnostic Role and Therapeutic Perspectives of Endoscopic Ultrasound for Pancreatic Neuroendocrine Tumor
}

\author{
Jun-Ho Choi \\ Department of Internal Medicine, Dankook University College of Medicine, Cheonan, Korea
}

Pancreatic neuroendocrine tumors (PNETs) are rare tumors with malignant potential, but their incidence has appreciably increased over the last few decades. Diagnosis of PNETs is often difficult with conventional imaging methods. Cross-sectional imaging localizes less than $10 \%$ of PNETs less than $1 \mathrm{~cm}$ in diameter. Endoscopic ultrasound (EUS) has been shown to be superior to other imaging techniques in the preoperative localization and diagnosis of PNETs. The finding of a hyperenhanced lesion on contrastenhanced EUS was highly predictive of PNETs different from adenocarcinoma. Preoperative assessment of tumor differentiation and $\mathrm{Ki}-67$ is an important prognostic factor for grading. Thus, EUS-guided fine needle biopsy may play a key role in the work-up of nonfunctioning PNETs, and attempts to measure Ki-67 on cytologic and histologic samples have been made. According to the European Neuroendocrine Tumor Society guidelines, there is no clear evidence of a survival benefit of surgery for nonfunctioning G1 PNETs $<2 \mathrm{~cm}$ in diameter. The benefits of curative surgery must be weighed against operative morbidity and mortality. Although surgical resection remains the mainstay for PNETs, EUS-guided ablation offers a relatively safe and effective treatment option in patients deemed unfit for, or who do not want to undergo, surgery. EUS-guided ablation provides an attractive therapeutic nonsurgical option for patients; however, further studies that better elucidate the long-term outcomes with standardization of technique will help define its role in the treatment of PNETs. The role of EUS in the diagnosis and treatment of PNETs is expected to make much progress in the future.

Korean J Pancreas Biliary Tract 2021;26(1):1-9

Keywords: Endosonography, Diagnosis, Therapeutics, Neuroendocrine tumors

$\begin{array}{ll}\text { Received } & \text { Dec. } 2,2020 \\ \text { Revised } & \text { Dec. 18, } 2020 \\ \text { Accepted } & \text { Dec. 18, 2020 }\end{array}$

Corresponding author : Jun-Ho Choi

Department of Internal Medicine, Dankook University College of Medicine, 201 Manghyang-ro, Dongnam-

gu, Cheonan 31116, Korea

Tel: +82-41-550-3086

Fax: +82-41-556-3256

E-mail: cjh@dankook.ac.kr

ORCID: https://orcid.org/0000-0002-8792-6249

This is an Open Access article distributed under the terms of the Creative Commons Attribution Non-Commercial License (http:// creativecommons.org/licenses/by-nc/3.0/) which permits unrestricted non-commercial use, distribution, and reproduction in any medium, provided the original work is properly cited.

Copyright $\odot 2021$ by The Korean Journal of Pancreas and Biliary Tract

\section{서 론}

췌장신경내분비종양(pancreatic neuroendocrine tumor, PNET)은 전체 원발성 췌장 종양의 약 $3 \%$ 이내를 차지하는
흔하지 않은 종양이다. ${ }^{1}$ PNET는 임상적으로 인슐린종과 같이 호르몬 과다분비에 의한 내분비병증(endocrinopathy)을 유발하는 기능성 PNET와 무증상의 비기능성 PNET로 나뉜다. 과거에는 다양한 임상 증상을 유발하는 기능성 PNET가 주된 
진단 치료의 대상이었으나, 최근에는 건강검진의 보급 및 영상 진단의 발전에 힘입어 무증상 PNET의 발견 빈도가 전체의 $50 \%$ 이상 증가하여 이에 대한 치료 역시 중요해지는 추세이다. 임상의가 PNET의 치료를 결정함에 있어서 기능성 여부, 병기, 유사분열의 등급 등이 중요한 기준이 된다. PNET는 수술적 치료가 기본 원칙이나, 크기가 작고 증상이 유발되지 않을 경우 수술을 할지 주기적인 검사를 하며 추적 관찰을 할지에 대해서 여전히 일치된 치료 방침은 없으며, 임상의의 판단에 따라 수술 여부를 결정하게 된다.

EUS의 개발로 췌장의 고형 종괴를 감별 진단하는 데 있어 필수적인 검사법으로 자리잡았다. 이는 선형 EUS 검사를 통해 췌장의 고형 종괴에 대한 EUS 유도하 세침흡인술(EUS-guided fine needle aspiration, EUS-FNA) 또는 조직학적 검사(fine needle biopsy, FNB)가 용이하기 때문이다. 단순히 EUS를 통해 구조물을 관찰하는 것을 넘어서 췌장 종양에 대한 미세혈관계와 관혈류(perfusion)의 특징을 부각시키기 위해 조영증강 EUS (contrast-enhanced endoscopic ultrasound, CE-EUS)가 개발되었고, 이를 통해 양성과 악성의 감별 능력을 향상시키고 국소 소작술(ablation therapy) 후 초기 치료 평가에도 도움을 줄 수 있다. ${ }^{3}$ 췌장 수술의 사망률과 이환율, 추적 검사에 따른 비용을 고려할 때 수술과 경과 관찰이라는 이분법적 치료 방침으로는 다양한 임상적 상황을 포용하기에 충분하지 않고, 수술 적응증을 점차 엄격하게 적용하는 것으로 진료 지침이 변화하고 있다. 최근 들어 EUS를 이용한 국소 소작술에 관한 여러 임상 연구가 보고되고 있다. 본고에서는 EUS가 PNET의 진단과 치료에 어떻게 활용되고 있는지에 대해 알아보고자 한다.

\section{본론}

\section{EUS의 진단적 역할}

1) EUS 및 EUS-FNA

(1) EUS에서 관찰되는 PNET의 특징

PNET에서 수술 전 병변의 위치를 명확히 파악하는 것이 무엇보다도 중요한데, computed tomography (CT), magnetic resonance imaging $(\mathrm{MRI})$ 등과 같은 전형적인 영상 검사가 임상에서 널리 활용되고 있다. PNET는 80-90\%에서 소마토스타틴 수용체를 발현하기 때문에 소마토스타틴 유사체를 추적자로 사용하는 octreotide scintigraphy가 영상 진단법으로 이용되고 있으며 CT나 MRI보다 예민도가 뛰어난 것으로 알려져 있다. 최근에는 68Ga-DOTA-TOC positron emission tomography (PET)-CT가 활용되고 있다. 신경내분비종양의 진단에서 68Ga-DOTA-TOC PET-CT 민감도와 특이도는 각각 $93 \%, 85 \%$ 로 비교적 높다고 알려져 있다. ${ }^{4}$

EUS는 췌장의 종양을 발견하는 데 있어서 높은 민감도로 주목을 받고 있다. PNET는 EUS에서 저에코 균질성 병변으로 비교적 경계가 뚜렷하게 나타난다(Fig. 1A). 췌장 종양을 진단하는 영상학적 기법을 비교한 연구에서, CT의 민감도는 $74 \%$ 였지만 EUS의 민감도는 $98 \%$ 에 달하였다. ${ }^{5} \mathrm{EUS}$ 는 고해상도 영상을 얻기 때문에 종양의 크기가 작을 경우 그 유용성이 크다. $3 \mathrm{~cm}$ 미만의 췌장 종양을 대상으로 영상학적 기법을 비교한 연구에서 CT의 민감도는 53\%였으나, EUS의 민감도는 $93 \%$ 에
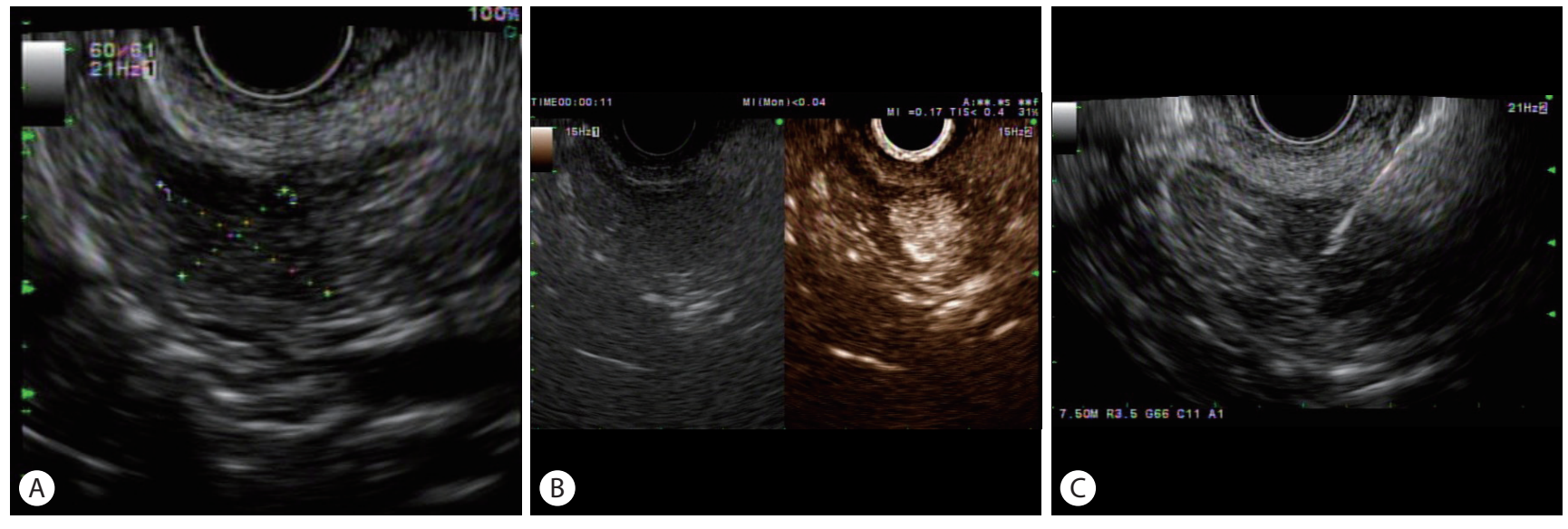

Fig. 1. (A) Endoscopic ultrasound shows about $1.5 \mathrm{~cm}$ sized hypoechoic mass in the head of pancreas. (B) On contrast-enhanced endoscopic ultrasound, hyperenhancement of the tumor was identified after injection of contrast agent. (C) Endoscopic ultrasound-guided fine needle biopsy of a pancreatic neuroendocrine tumor. 
달하였으며 $67 \%$ 의 민감도를 보인 MRI보다 더 우월하였다. ${ }^{6}$ 임상적으로 PNET가 의심되지만 CT에서 종양이 뚜렷하게 보이지 않는 경우에는 EUS를 반드시 고려해봐야 하겠다. 하지만 EUS를 능숙하게 다루기까지 내시경 의사의 많은 경험이 필요하며, 초음파 특성상 투과도의 한계로 인하여 심부에 위치한 종양을 파악하기 어려운 단점도 있다. CT나 MRI 등 기존의 영상학적 기법과 상호 보완적인 관계로 진단에 이용하는 것이 바람직하다.

(2) EUS 유도하 표식법(EUS-guided fine needle tattooing, EUS-FNT)

크기가 $2 \mathrm{~cm}$ 미만의 PNET에서 췌장 실질을 가능한 보존하는 단순종양적출술(enucleation)과 같은 최소 침습 수술이 늘어나면서, 정확한 병변 위치를 파악하기 위해 EUS-FNT의 시도가 보고되었다(Table 1).-11

인디아 잉크(india ink)는 탄소 입자의 콜로이드성 현탁액으로 에틸렌 글라이콜(ethylene glycol), 젤라틴(gelatin), 페놀(phenol), 셜락(shellac)과 같은 물질을 포함하는데, 이러한 물질들이 염증성 반응을 유발할 수 있다. ${ }^{12}$ 이를 줄이기 위해 고온 고압 처리를 하거나 항균 처리된 필터에 여과시킨 뒤, 생리식염수에 $1: 100$ 으로 희석시켜 사용할 것을 권장하고 있다. ${ }^{12}$ 인디아 잉크 이외에 메틸렌 블루(methylene blue), indocyanine green (ICG) 등이 동물 실험에서 평가받았으나, 인디아 잉크와 ICG만이 표식 후 48 시간까지 확인 가능하였다. ${ }^{12}$ 인디아 잉크와 ICG는 현재까지 국내 식품의약품안전처의 허가를 받지 못하였다. 인디아 잉크에 포함되어 있는 염증성 반응 물질들을 제거한 후 살균 및 희석 처리를 한 제품인 Spot ink ${ }^{\circledR}$ (GI Supply, Camp Hill, PA, USA)가 미국 식품의약국(US Food and Drug
Administration)의 승인을 받아 상용화되어 있으나, 이 제품 역시 아직까지 국내 식품의약품안전처의 허가를 받지 못하였다. ${ }^{12}$ 표식을 위한 다른 대안으로 EUS를 이용하여 종양 내에 금으로 된 방사선 표지자(fiducial)를 삽입하는 시술도 보고되었다. ${ }^{13,14}$

\section{(3) EUS-FNA를 통한 진단}

췌장의 고형 종양은 PNET 이외에도 고형 가성유두상 종양, 췌장선암, 선상세포암(acinar cell carcinoma), 선편평상피암 (adenosquamous carcinoma) 등이 있으며, 림프종, 폐암이나 신장암의 췌장 전이 또는 골수 외 형질세포종의 췌장 침범 등도 있다. 이러한 췌장 고형 종양의 감별 진단은 영상학적 검사만으로 한계가 있으며 병리학적 진단이 중요하다. 신경내분비종양은 개개의 세포는 균일한데 반해 배열 양상은 특징적으로 기관을 형성하는 듯한 모양(organoid), 즉 소(nest)형성, 세포주모양, 샘모양, 관소엽모양 등 다양한 모습을 취한다. 개별 세포는 중심에 위치한 핵은 미세한 과립 모양이고 핵소체가 작지만 뚜렷하며 세포질은 과립성이다. 신경내분비종양 표지자인 chromogranin A 및 synaptophysin에 양성으로 염색되며, 진단을 하기 위해서는 최소한 이 중 한 가지 표지자에서 양성이어야 한다. ${ }^{15}$

EUS-FNA를 통하여 수술 전 병리학적 진단이 가능하며, 최근 다양한 EUS용 세침의 개발로 진단율이 $90 \%$ 이상 상승하였다(Fig. 1C). 최근 연구에서 췌장 고형 종양을 진단하는 데 있어서 EUS-FNA의 민감도는 85-92\%, 특이도는 96-98\%로 보고되었다. ${ }^{16,17}$ EUS-FNA는 높은 민감도와 특이도를 보여주며, 활용도가 높음에도 $1-2 \%$ 의 낮은 합병증(출혈, 췌장염, 감염, 천공)을 보이는 장점이 있다. ${ }^{18}$

Table 1. Summary of the studies evaluating endoscopic ultrasound-guided marking of pancreatic neuroendocrine tumors to guide surgical resection

\begin{tabular}{|c|c|c|c|c|c|c|c|c|}
\hline Study & Diagnosis & $\begin{array}{l}\text { No of } \\
\text { pts. }\end{array}$ & $\begin{array}{c}\text { Lesion } \\
\text { size }(\mathrm{mm})\end{array}$ & $\begin{array}{l}\text { Needle } \\
\text { gauge }\end{array}$ & Method & Quantity & $\begin{array}{l}\text { Intraoperative } \\
\text { recognition }\end{array}$ & $\begin{array}{c}\text { Adverse } \\
\text { events }\end{array}$ \\
\hline Gress et al. (2002) & F-PNET & 1 & $19 \times 5$ & 22 & India ink injection & $4 \mathrm{~mL}$ & Yes & None \\
\hline Zografos et al. ${ }^{8}$ (2010) & F-PNET & 1 & $9.8 \times 8.2$ & NR & Methylene blue & $1 \mathrm{~mL}$ & Yes & None \\
\hline Rodriguez et al. ${ }^{9}$ (2011) & F-PNET & 1 & 9 & NR & Spot ink ${ }^{\circledast}$ & $N R$ & Yes & None \\
\hline Law et al. ${ }^{14}(2013)$ & $\begin{array}{l}\text { F-PNET and } \\
\text { NF-PNET }\end{array}$ & 2 & 8 & 22 & Fiducials implantation & $\begin{array}{c}2 \\
\text { fiducials }\end{array}$ & $100 \%$ & None \\
\hline Leelasinjaroen et al..$^{10}$ (2014) & F-PNET & 1 & 15.5 & 22 & Spot ink ${ }^{\oplus}$ & $2 \mathrm{~mL}$ & Yes & None \\
\hline Okuzono et al..11 (2016) & PNET & 1 & 7 & 25 & $\begin{array}{l}\text { India ink and sodium } \\
\text { hyaluronate }\end{array}$ & $0.1 \mathrm{~mL}$ & Yes & None \\
\hline
\end{tabular}

F-PNET, functional pancreatic neuroendocrine tumor; NF-PNET, non-functional pancreatic neuroendocrine tumor; NR, not reported. 
(4) 병기 분류에서 EUS의 활용

PNET의 조직학적 분화도는 예후를 예측하는 데 가장 중요한 인자이다. ${ }^{19}$ PNET는 종양의 완전 절제가 기본 원칙이지만, 분화도가 좋고 $(\mathrm{Gl})$ 크기가 $2 \mathrm{~cm}$ 미만인 경우에는 추적 관찰할수 있다. 2010년 세계보건기구(World Health Organization) 분류에서 신경내분비종양 대신 신경내분비신생물이라는 좀 더 포괄적인 명칭을 사용하였고, 등급 분류의 기준은 10 개의 고배율시야당 세포분열수와 Ki-67 세포증식지수이다. G1은 세포분열수가 10 개의 고배율시야당 2 개 미만과 Ki-67 세포증식지수 $2 \%$ 이하일 때, G2는 세포분열수가 10 개의 고배율시야당 2-20개 또는 Ki-67 세포증식지수가 3-20\% 사이일 때, G3은 세포분열수가 10 개의 고배율시야당 20 개 이상 또는 $\mathrm{Ki}-67$ 세포증식지수가 $20 \%$ 이상일 때로 정한다. ${ }^{20}$ 최근 연구 결과에서는 Ki-67 세포증식지수 20\% 이상에서 세포 분화도에 따라 치료 반응과 예후에 차이를 보이는 것을 예측하여, 2017년 세계보건기구 분류에서는 G3를 고분화 신경내분비종양과 저분화 신경내분비암으로 구분하여 명명하고 있다(Table 2). ${ }^{21}$

Larghi 등리 시행한 연구에서는 PNET 30예 중 EUS 유도하 조직생검을 통하여 진단에 충분한 조직을 획득한 환자는 93\%였고, Ki-67 세포증식지수 분류가 가능한 환자는 $87 \%$ 였다. Leeds 등 $^{23}$ 의 연구에서는 FNB needle이 전통적인 FNA needle보다 조직 획득률이나 Ki-67 세포증식지수 분류 등에서 우수함을 보고하였다. 따라서 PNET의 진단 뿐만 아니라 병기 분류를 위해 EUS-FNB를 시행하여 진단의 정확성을 높이고 치료 방침 결정에 도움이 될 수 있겠다. 향후 PNET의 예후인자 및 악성도 평가의 중요성은 더욱 커지고 있으며 Ki-67 지수의 활용도가 높아질 것으로 생각된다.

\section{2) CE-EUS}

(1) 초음파 조영제의 종류와 특성

초음파 조영제에는 여러 종류가 있으며 현재 우리나라에서 사용이 가능한 것은 2 세대 초음파 조영제로서, SonoVue ${ }^{\circledR}$ (Bracco, Milano, Italy)와 2012년에 국내 출시되어 한국과 일본에서 사용되기 시작한 Sonazoid ${ }^{\circledR}$ (Daiichi Sankyo, Tokyo, Japan)가 췌장 종괴 감별에 이용되고 있다. ${ }^{3}$ 이들 기체를 싸고 있는 지질막은 조영제에 따라 다소 차이가 있으며, 미세기포는 대부분이 2-10 um 전후 크기로 적혈구와 비슷하여, 모세혈관을 잘 통과하기 때문에 말초정맥으로 주사하더라도 우심계와 폐를 통과해서 좌심계를 통해서 전신 순환이 가능하게 되어 목표 장기에 도달하게 된다. 낮은 음향 파워에서의 특별한 음역 순서(acoustic sequence)는 미세기포에 공명을 유발하여 실시간 하모닉 영상을 가능하게 한다. ${ }^{24}$ 과거 1 세대 초음파 조영제를 사용하였을 때는 EUS의 탐촉자 크기가 작아 충분한 음향 파워가 발생되지 않아 조영증강 하모닉 영상 기술이 불가능하였다. ${ }^{24}$ SonoVue ${ }^{\circledR}, S_{\text {Sonazoid }}{ }^{\circledR}$ 와 같은 2 세대 초음파 조영제는 perfluorocarbon과 sulfur hexafluoride와 같은 불용성이면서 확산성을 갖는 물질로 둘러 싸여져 있는 미세기포로서 낮은 음향 파워에서도 하모닉 신호 생성이 가능하여 EUS 영역에서도 CE-EUS가 가능하게 되었다. ${ }^{25}$ 초음파 조영제 주입 후 $15-20$ 초에 췌장에 도달하고 30-45초 동맥기, 이후 60초까지 정맥기이며, 이 과정에서 혈관성의 변화를 탐지하여 종양들을 특성화 할 수 있다. ${ }^{24,25}$

초음파 조영제는 신독성이 없다는 큰 장점을 가지고 있어 일반적인 CT를 시행하기 어려운 경우에도 안전하게 시행할 수 있고 조영제에 대한 과민반응도 매우 드문 것으로 보고되고 있다. ${ }^{25}$ CT와 달리 반복적인 검사에도 방사선 노출의 위험이 없다는 것이장점이다. ${ }^{26}$

Table 2. WHO (2017) nomenclature and classification of pancreatic neuroendocrine tumors

\begin{tabular}{lcccc}
\hline WHO & Differentiation & Grade & Mitoses/10 HPF & Ki-67 index \\
\hline NET, G1 & Well-differentiated & Low & $<2$ & $<3 \%$ \\
NET, G2 & Well-differentiated & Intermediate & $2-20$ & $3-20 \%$ \\
NET, G3 & Well-differentiated & High & $>20$ & $>20 \%$ \\
NEC, small cell type (SCNEC) & Poorly-differentiated & High & $>20$ & $>20 \%$ \\
NEC, large cell type (LCNEC) & Poorly-differentiated & High & $>20$ & $>20 \%$ \\
\hline
\end{tabular}

NET, neuroendocrine tumor; NEC, neuroendocrine carcinoma; HPF, high power field. 


\section{(2) CE-EUS의 임상적 활용}

EUS는 췌장 종괴를 인지하는 데 매우 정밀한 검사이나, PNET, 췌장암 그리고 종괴 형성 췌장염은 EUS로 관찰하였을 때 대개 저에코성(hypoechoic) 음영으로 관찰되기 때문에 EUS 소견만으로 이런 종양들을 감별하는 것이 어려울 수 있다. CE-EUS는 종양의 특성을 파악하고 감별하는 데 도움이 된다. ${ }^{27}$

PNET는 미세혈관이 풍부하게 발달되어 있기 때문에 과혈관성(hyperenhancing lesion)으로 보인다(Fig. 1B). PNET의 크기가 작은 경우에는 CE-EUS에서 좀 더 선명하게 관찰된다. 반면 조영증강 동안 관류가 잘되지 않는 경우를 저혈관성 (hypoenhancing lesion)이라 분류하는데, 이는 선암을 시사하는 소견이다. ${ }^{28}$ 종괴형성 만성 췌장염의 경우 동맥기에서 등혈관성(isoenhancing lesion)을 보이다가 정맥기에서 저혈관성을 보이는 특징이 있다. 한 연구에서 PNET을 진단하는 데 있어 과혈관성 패턴을 적용하였을 때 민감도는 $93 \%$, 특이도는 $88 \%$ 정도의 결과를 보여주었다. ${ }^{29}$ 최근 메타 연구에 의하면 CE-EUS는 췌장 종양을 감별하는 데 있어서 $93-94 \%$ 의 민감도와 $88-89 \%$ 의 특이도를 보인다. ${ }^{30}$

CE-EUS는 종양의 EUS 유도하 치료에 있어서 정확성과 성공률을 올리기 위한 가이드 역할을 하고 있고 치료 후의 치료 반응 평가에서도 유용한 것으로 알려져 있다. ${ }^{26,31}$ 특히 고주파열절제술(radiofrequency ablation, RFA) 등의 국소 치료 시
B-mode EUS 영상에서 치료 목표 병변이 분명하지 않은 경우 병변을 찾는 데에 도움이 된다. ${ }^{31} \mathrm{PNET}$ 의 국소 치료 후 CE-EUS를 시행하여 치료 병변의 잔존 또는 재발을 파악하는 데 도움이 되며, 잔존 부위에 고주파 소작 전극의 정확한 유도에 이용할 수 있다. ${ }^{31}$

\section{EUS의 치료적 활용}

\section{1) 내시경 치료 도입 배경}

가장 기본적인 치료법은 외과적으로 완전히 절제하는 것이다. 그러나 췌장 수술은 난이도가 높은 수술로서 20-30\%의 이환율과 $1-3 \%$ 의 사망률이 수반되므로 증상이 없거나 악성 변화의 가능성이 높지 않은 경우에 수술을 시행하는 것은 의사와 환자 모두에게 상당한 부담이 된다. European Neuroendocrine Tumor Society 가이드라인에 따르면 $2 \mathrm{~cm}$ 미만의 전이의 증거가 없는 PNET이 유사분열 등급이 낮을 경우 수술적 절제 없이 추적 관찰하되 $5 \mathrm{~mm}$ 이상 크기가 성장하거나 $20 \mathrm{~mm}$ 이상으로 크기가 증가할 경우 수술적 절제를 권고한다. ${ }^{15}$ 한편 2020년 National Comprehensive Cancer Network 가이드라인에서는 전이가 없는 PNET에 대해서 금기가 없다면 수술적 절제를 하되, 크기가 $2 \mathrm{~cm}$ 미만인 G1 PNET라면 경과 관찰을 해볼 수 있다고 권고하고 있다.

Table 3. Summary of the studies evaluating fine needle injection therapy for treatment of pancreatic neuroendocrine tumors

\begin{tabular}{|c|c|c|c|c|c|c|c|}
\hline Study & Diagnosis & No. of pts & $\begin{array}{l}\text { Mean size } \\
(\mathrm{mm})\end{array}$ & Method & $\begin{array}{l}\text { Total no. of } \\
\text { sessions }\end{array}$ & $\begin{array}{l}\text { Effectiveness } \\
\text { (\%) }\end{array}$ & $\begin{array}{l}\text { Adverse events } \\
\text { (no.) }\end{array}$ \\
\hline Jürgensen et al. ${ }^{32}$ (2006) & Insulinoma & 1 & 13 & Ethanol & 1 & 100 & Mild pancreatitis (1) \\
\hline Muscatiello et al. ${ }^{33}$ (2008) & VIPoma & 1 & 11 & Ethanol & 2 & 100 & Pancreatic necrosis (1) \\
\hline Deprez et al..$^{34}(2008)$ & Insulinoma & 1 & 17 & Ethanol & 1 & 100 & Bleeding (1) \\
\hline Vleggaar et al. ${ }^{35}$ (2011) & Insulinoma & 1 & 1 & Ethanol & 1 & 100 & None \\
\hline Yang et al. ${ }^{36}(2015)$ & Insulinoma & 4 & NR & Ethanol & 5 & 75 & None \\
\hline Teoh et al. ${ }^{37}$ (2015) & NF-PNET & 1 & 10 & Ethanol & 1 & 100 & None \\
\hline Park et al. ${ }^{38}$ (2015) & $\begin{array}{l}\text { Insulinoma } \\
\text { NF-PNET }\end{array}$ & $\begin{array}{l}2 \\
9\end{array}$ & $\begin{array}{c}12.5 \\
11\end{array}$ & Ethanol & $\begin{array}{c}5 \\
12\end{array}$ & $\begin{array}{c}75 \\
62.5\end{array}$ & $\begin{array}{l}\text { Abdominal pain (1): pancreatitis } \\
\text { (3) with MPD stricture (1) }\end{array}$ \\
\hline Paik et al. ${ }^{39}$ (2016) & $\begin{array}{c}\text { Insulinoma } \\
\text { Gastrinoma } \\
\text { NF-PNET }\end{array}$ & $\begin{array}{l}3 \\
1 \\
2\end{array}$ & $\begin{array}{c}11 \\
9 \\
12.5\end{array}$ & Ethanol & $\begin{array}{l}3 \\
1 \\
2\end{array}$ & $\begin{array}{c}100 \\
100 \\
50\end{array}$ & $\begin{array}{l}\text { Abdominal pain (1); Fever (1); } \\
\text { Severe pancreatitis (1) }\end{array}$ \\
\hline Choi et al. ${ }^{40}$ (2018) & $\begin{array}{l}\text { NF-PNET } \\
\text { Insulinoma }\end{array}$ & $\begin{array}{c}32 \\
1\end{array}$ & 11 & $\begin{array}{l}\text { Ethanol- } \\
\text { Lipiodol }\end{array}$ & 76 & 60 & $\begin{array}{l}\text { Pancreatitis (2) with MPD } \\
\text { stricture (1) }\end{array}$ \\
\hline Silva et al. ${ }^{42}(2019)$ & Insulinoma & 1 & 21 & Ethanol & 1 & 10 & None \\
\hline Matsumoto et al. ${ }^{41}$ (2020) & NF-PNET & 5 & 10 & Ethanol & 8 & 80 & None \\
\hline
\end{tabular}

MPD, main pancreatic duct. 
수술 혹은 추적 관찰의 이분법적 관점은 임상 진료에 있어서는 많은 고민을 안겨주는데, 최소 침습적인 치료 방법으로 종양을 제거할 수 있다면 수술에 따른 위험을 피하고 경과 관찰에 따른 부담도 최소화할 수 있을 것이다. 이러한 점을 보완할 수 있는 치료 방법으로 PNET에서 EUS 유도하 제거술(EUS-guided ablation therapy)이 시도되었다. 기술적으로는 시행 가능하다는 것이 증명되었지만, 실제적인 치료 효과와 적절한 적응증에 대해서는 정립된 바가 없기에 기저질환에 의해 수술적 치료를 받기 어렵거나 수술을 기피하는 환자, 추적 관찰에 수반되는 악성변화의 불안감 및 반복적인 고비용 검사에 대한 경제적 부담이 있는 환자 등에서 내시경 치료를 고려해 볼 수 있겠다.

\section{2) PNET의 내시경 치료}

(1) EUS-guided fine needle injection (EUS-FNI) and ablation 췌장 고형 종양의 경우 낭성종양에 비하여 연구가 적은 실정으로 인슐린종과 무증상 PNET를 대상으로 소수의 증례보고 형식으로 보고되었으며 완전 관해율은 60-100\% 정도로 알려져 있다(Table 3). ${ }^{32-42}$ 그러나 아직까지 급성 췌장염, 췌관 손상, 혈관 손상, 감염, 재발 등의 시술 관련 안전성이 확립되어 있지 않다. 2006년 Jürgensen 등 ${ }^{32}$ 이 최초로 에탄올을 이용한 소작술을 인슐린종에 적용한 증례를 보고하였고, 저혈당 증세가 호전됨을 보고한 이후, 에탄올의 소작효과는 여러 소규모 임상시험을 통해 보고되었다. 에탄올은 낮은 점도로 작은 두께의 바늘을 통하여 쉽게 주입이 가능하고, 가격이 저렴하며, 조직의 괴사를 일으키고 섬유화 작은 혈관의 혈전을
유도한다. Park 등 ${ }^{38}$ 은 11 명을 대상으로 에탄올을 이용한 소작술을 시행한 이후 완전관해율을 $61 \%$ 로 보고하였으나, 합병증은 $27 \%$ 에서 확인되어서 에탄올 소작술의 안전성에 의문을 제기하였다.

이후 에탄올과 리피오돌(lipiodol) 혼합액을 이용한 소작술이 시도되었는데, 리피오돌의 소수성과 높은 점도로 인하여 종양 캡슐 내부에 잘 저류되어 유출을 최소화하여 췌장염 위험도를 낮추고, 미세혈관 색전을 유도하여 치료 효과를 높일 것으로 기대되었다. ${ }^{40}$ 또한 리피오돌은 방사선 비투과성이므로 시술 도중 방사선 투시기(fluoroscopy)로 관찰하면 리피오돌 혼합액의 흐름을 실시간으로 확인할 수 있는 장점이 있다. Choi 등 ${ }^{40}$ 은 PNET에 대해 EUS 유도하 에탄올-리피오돌 소작술을 시행한 33 명의 데이터를 분석한 결과, 완전관해는 $60 \%$ 수준으로 확인되었고, 전체 합병증은 $3 \%$ 에서 보고되었다. 이 연구에서 시술 후 완전관해의 예측인자로 리피오돌 종양 내 침착 (retention)이 확인되었다. 향후 시술의 적절한 적응증과 치료 효과를 예측할 때 이러한 특성들을 적용하여 진행하는 것이 필요하겠다.

\section{(2) EUS-RFA}

최근에는 EUS-RFA를 시행한 연구 결과가 발표되고 있다(Table 4). ${ }^{43-49} \mathrm{RFA}$ 는 국소적으로 높은 열을 주어 세포에 손상을 주고 자멸사를 유도하고 괴사를 일으키는 방식으로, 최근 동물실험 결과를 바탕으로 PNET에 대한 적용이 시도되고 있다. ${ }^{50}$ Choi 등 ${ }^{48}$ 은 10 명의 환자를 대상으로 EUS-RFA를 시행하였고 모든 환자에서 중증 합병증 없이 시술에 성공하면서

Table 4. Summary of the studies evaluating treatment of pancreatic neuroendocrine tumors with endoscopic ultrasound-guided radiofrequency ablation

\begin{tabular}{|c|c|c|c|c|c|c|c|c|c|}
\hline Study & Diagnosis & $\begin{array}{c}\text { No. of } \\
\text { pts }\end{array}$ & $\begin{array}{l}\text { Lesion size } \\
(\mathrm{mm})\end{array}$ & $\begin{array}{l}\text { Needle } \\
\text { gauge }\end{array}$ & $\begin{array}{l}\text { Power } \\
\text { (W) }\end{array}$ & $\begin{array}{c}\text { No. of } \\
\text { sessions }\end{array}$ & $\begin{array}{c}\text { Effectiveness } \\
(\%)\end{array}$ & $\begin{array}{c}\text { Adverse events } \\
\text { (no.) }\end{array}$ & $\begin{array}{l}\text { Follow-up } \\
\text { (months) }\end{array}$ \\
\hline Armellini et al. ${ }^{43}$ (2015) & NF-PNET & 1 & 20 & 18 & NR & 1 & 100 & None & 1 \\
\hline Pai et al. ${ }^{44}(2015)$ & NF-PNET & 2 & 27.5 & $19 \& 22$ & 20 & 1.5 & 100 & None & NR \\
\hline Lakhtakia et al. ${ }^{45}$ (2016) & Insulinoma & 3 & 16.7 & 19 & 50 & 1 & 100 & None & 10.3 \\
\hline Waung et al. ${ }^{47}$ (2016) & Insulinoma & 1 & 18 & 19 & 10 & 3 & 100 & None & 10 \\
\hline Bas-Cutrina et al. ${ }^{46}$ (2017) & Insulinoma & 1 & 10 & 22 & 10 & 1 & 100 & None & 10 \\
\hline Choi et al..$^{40}(2018)$ & $\begin{array}{l}\text { NF-PNET } \\
\text { Insulinoma }\end{array}$ & $\begin{array}{l}7 \\
1\end{array}$ & $\begin{array}{c}20.3 \\
12\end{array}$ & $18 \& 19$ & 50 & $\begin{array}{c}1.9 \\
1\end{array}$ & $\begin{array}{l}71.4 \\
100\end{array}$ & $\begin{array}{l}\text { Abdominal pain (1); } \\
\text { pancreatitis (1) }\end{array}$ & 13 \\
\hline Barthet $^{49}(2019)$ & NF-PNET & 12 & 13.1 & 18 & 50 & NR & 71.4 & $\begin{array}{c}\text { Pancreatitis (1); fever (1); } \\
\text { pancreatic necrosis } \\
\text { (1); MPD stenosis (1) }\end{array}$ & 12 \\
\hline
\end{tabular}

MPD, main pancreatic duct. 
$70 \%$ 에서 완전 관해에 도달하였음을 보고하였다. 아직 시술의 효과에 대하여 논하기는 이른 것으로 보이며 향후 대규모 전향적 연구가 필요할 것으로 보인다. ${ }^{48}$

지금까지의 연구 결과를 토대로 PNET의 치료에 있어서 EUS 유도하 소작술의 기대되는 역할은 악성의 가능성이 낮은 PNET에 대한 불필요한 수술을 줄여 수술의 합병증을 피할 수 있게 하고, 추적 관찰 목적의 영상 검사를 줄여줄 수 있다는 점이다. 이러한 효과를 얻기 위해서는 적절한 적응증을 통해 시술을 해야 하며, 전이가 없는 $2 \mathrm{~cm}$ 이하의 G1 PNET 그리고 수술의 위험성이 높거나 수술을 거부한 환자에서 시도해볼 수 있을 것으로 생각된다.

\section{결 론}

췌장의 신경내분비종양은 흔하지 않은 종양으로 알려져 있지만, 최근 들어 검강검진의 보급 및 영상 진단법의 발전에 힘입어 꾸준히 진단이 늘고 있고, 특히 무증상의 작은 PNET의 발견이 많아지고 있다. EUS는 PNET의 진단 및 치료에 점차 다양한 방식으로 활용되고 있다. PNET의 정확한 진단과 위치 확인은 치료전략을 결정하기에 매우 중요한데, 임상적으로 의심되나 컴퓨터 단층촬영이나 자기공명영상에서 진단이 불확실한 경우, EUS를 추가적인 정보를 얻는 데 활용할 수 있다. CE-EUS는 췌장 고형성 병변을 특성화하고, 감별 진단에 유용하다. EUS 유도하 조직 검사를 시행하여 정확한 진단 및 병기 분류에 대한 정보를 얻을 수 있다.

EUS는 진단뿐 아니라 치료에서 그 역할이 강조되고 있으며, 각종 시술의 패러다임이 환자에게 더 편안하고 안전하면서 덜 침습적인 것을 추구하면서 $\mathrm{EUS}$ 를 이용한 중재술이 빠르게 개발, 발전하고 있다. 그러나 아직까지 대부분의 EUS 관련 치료법은 연구 단계인 경우가 많기에, 무분별한 시술 및 비윤리적인 임상시험 등에 주의가 요구되고, 후속 연구를 통하여 이를 적용할 적절한 적응증과 실제 치료 효과를 증명할 높은 수준의 근거가 필요하겠다.

\section{요 약}

EUS는 탐촉자를 위나 십이지장에 위치시킬 수 있어 췌장에서 가장 가까운 곳에서 췌장을 관찰할 수 있으므로 매우 작은 췌장
종괴도 인지할 수 있다. 또한 종괴 자체에 대한 감별이 어려울 경우 EUS를 통한 조직 검사는 합병증을 최소화하면서 조직학적 확진율을 높일 수 있다. CE-EUS는 종괴의 특성을 파악하기 어려울 때 도움이 된다. 진단뿐만 아니라 치료에서도 EUS를 활용하고 있는데, 에탄올을 이용한 화학적 소작술 또는 RFA 수술 혹은 경과 관찰이라는 이분법적 치료 방식의 간극을 메워주는 비수술적 치료 방법으로 새롭게 시도되고 있다. PNET의 진단 및 치료에 EUS는 다양하게 활용되고 있으며, 향후 지속적인 발전이 기대된다.

국문 색인: 초음파 내시경, 진단, 치료, 췌장신경내분비종양

\section{Conflicts of Interest}

The author has no conflicts to disclose.

\section{REFERENCES}

1. Oberg K, Eriksson B. Endocrine tumours of the pancreas. Best Pract Res Clin Gastroenterol 2005;19:753-781.

2. Franko J, Feng W, Yip L, Genovese E, Moser AJ. Non-functional neuroendocrine carcinoma of the pancreas: incidence, tumor biology, and outcomes in 2,158 patients. J Gastrointest Surg 2010;14:541-548.

3. Choi JH, Seo DW. The expanding role of contrast-enhanced endoscopic ultrasound in pancreatobiliary disease. Gut Liver 2015;9:707713.

4. Yang J, Kan Y, Ge BH, Yuan L, Li C, Zhao W. Diagnostic role of Gallium-68 DOTATOC and Gallium-68 DOTATATE PET in patients with neuroendocrine tumors: a meta-analysis. Acta Radiol 2014;55:389398.

5. Kitano M, Yoshida T, Itonaga M, Tamura T, Hatamaru K, Yamashita $Y$. Impact of endoscopic ultrasonography on diagnosis of pancreatic cancer. J Gastroenterol 2019;54:19-32.

6. Müller MF, Meyenberger C, Bertschinger P, Schaer R, Marincek B. Pancreatic tumors: evaluation with endoscopic US, CT, and MR imaging. Radiology 1994;190:745-751.

7. Gress FG, Barawi M, Kim D, Grendell JH. Preoperative localization of a neuroendocrine tumor of the pancreas with EUS-guided fine needle tattooing. Gastrointest Endosc 2002;55:594-597.

8. Zografos GN, Vasiliadis G, Karoubalis J, Tsagarakis S. Laparoscopic resection of insulinoma after endoscopic ultrasonography tattooing. Am Surg 2010;76:446-448.

9. Rodriguez A, Canto MI, Makary MA. Endoscopic localization and tattooing of a proinsulinoma for minimally invasive resection. Pancreas 2011;40:474-477.

10. Leelasinjaroen P, Manatsathit W, Berri R, Barawi M, Gress FG. Role of 
preoperative endoscopic ultrasound-guided fine-needle tattooing of a pancreatic head insulinoma. World J Gastrointest Endosc 2014;6:506509.

11. Okuzono T, Kanno Y, Nakahori M, et al. Preoperative endoscopic ultrasonography-guided tattooing of the pancreas with a minuscule amount of marking solution using a newly designed injector. Dig Endosc 2016:28:744-748.

12. ASGE Technology Committee, Kethu SR, Banerjee S, et al. Endoscopic tattooing. Gastrointest Endosc 2010;72:681-685.

13. Choi JH, Seo DW, Park DH, Lee SK, Kim MH. Fiducial placement for stereotactic body radiation therapy under only endoscopic ultrasonography guidance in pancreatic and hepatic malignancy: practical feasibility and safety. Gut Liver 2014;8:88-93.

14. Law JK, Singh VK, Khashab MA, et al. Endoscopic ultrasound (EUS)guided fiducial placement allows localization of small neuroendocrine tumors during parenchymal-sparing pancreatic surgery. Surg Endosc 2013;27:3921-3926.

15. Falconi M, Eriksson B, Kaltsas $G$, et al. ENETS consensus guidelines update for the management of patients with functional pancreatic neuroendocrine tumors and non-functional pancreatic neuroendocrine tumors. Neuroendocrinology 2016;103:153-171.

16. Turner BG, Cizginer S, Agarwal D, Yang J, Pitman MB, Brugge WR. Diagnosis of pancreatic neoplasia with EUS and FNA: a report of accuracy. Gastrointest Endosc 2010;71:91-98.

17. Eloubeidi MA, Varadarajulu S, Desai $S$, et al. A prospective evaluation of an algorithm incorporating routine preoperative endoscopic ultrasound-guided fine needle aspiration in suspected pancreatic cancer. J Gastrointest Surg 2007;11:813-819.

18. Wiersema MJ, Vilmann P, Giovannini M, Chang KJ, Wiersema LM. Endosonography-guided fine-needle aspiration biopsy: diagnostic accuracy and complication assessment. Gastroenterology 1997;112:10871095.

19. Khan MS, Luong TV, Watkins J, Toumpanakis C, Caplin ME, Meyer T. A comparison of $\mathrm{Ki}-67$ and mitotic count as prognostic markers for metastatic pancreatic and midgut neuroendocrine neoplasms. Br J Cancer 2013;108:1838-1845.

20. Cho CM. Recent updates in the management of advanced pancreatic neuroendocrine tumors. Korean J Gastroenterol 2019;73:124-131.

21. Guilmette JM, Nosé V. Neoplasms of the neuroendocrine pancreas: an update in the classification, definition, and molecular genetic advances. Adv Anat Pathol 2019;26:13-30.

22. Larghi A, Capurso G, Carnuccio A, et al. Ki-67 grading of nonfunctioning pancreatic neuroendocrine tumors on histologic samples obtained by EUS-guided fine-needle tissue acquisition: a prospective study. Gastrointest Endosc 2012;76:570-577.

23. Leeds JS, Nayar MK, Bekkali NLH, et al. Endoscopic ultrasound-guided fine-needle biopsy is superior to fine-needle aspiration in assessing pancreatic neuroendocrine tumors. Endosc Int Open 2019;7:E1281E1287.
24. Kitano M, Sakamoto H, Komaki T, Kudo M. New techniques and future perspective of EUS for the differential diagnosis of pancreatic malignancies: contrast harmonic imaging. Dig Endosc 2011;23(suppl 1):46-50.

25. Kitano M, Sakamoto $H$, Kudo M. Endoscopic ultrasound: contrast enhancement. Gastrointest Endosc Clin N Am 2012;22:349-358, xi.

26. Choi JH, Seo DW. Applications of contrast-enhanced harmonic endoscopic ultrasound on biliary, focal liver lesions and vascular diseases. Endosc Ultrasound 2017;6:21-24.

27. Lee TY, Cheon YK, Shim CS. Clinical role of contrast-enhanced harmonic endoscopic ultrasound in differentiating solid lesions of the pancreas: a single-center experience in Korea. Gut Liver 2013;7:599604.

28. Kitano M, Kudo M, Yamao K, et al. Characterization of small solid tumors in the pancreas: the value of contrast-enhanced harmonic endoscopic ultrasonography. Am J Gastroenterol 2012;107:303-310.

29. Fusaroli P, Spada A, Mancino MG, Caletti G. Contrast harmonic echo-endoscopic ultrasound improves accuracy in diagnosis of solid pancreatic masses. Clin Gastroenterol Hepatol 2010;8:629-634.e1-2.

30. Gong TT, Hu DM, Zhu Q. Contrast-enhanced EUS for differential diagnosis of pancreatic mass lesions: a meta-analysis. Gastrointest Endosc 2012;76:301-309.

31. Choi JH, Seo DW, Song TJ, et al. Utility of contrast-enhanced harmonic endoscopic ultrasound for the guidance and monitoring of endoscopic radiofrequency ablation. Gut Liver 2020;14:826-832.

32. Jürgensen C, Schuppan D, Neser F, Ernstberger J, Junghans U, Stölzel U. EUS-guided alcohol ablation of an insulinoma. Gastrointest Endosc 2006;63:1059-1062.

33. Muscatiello N, Nacchiero M, Della Valle N, et al. Treatment of a pancreatic endocrine tumor by ethanol injection (PEI) guided by endoscopic ultrasound. Endoscopy 2008;40(suppl 2):E83.

34. Deprez PH, Claessens A, Borbath I, Gigot JF, Maiter D. Successful endoscopic ultrasound-guided ethanol ablation of a sporadic insulinoma. Acta Gastroenterol Belg 2008;71:333-337.

35. Vleggaar FP, Bij de Vaate EA, Valk GD, Leguit RJ, Siersema PD. Endoscopic ultrasound-guided ethanol ablation of a symptomatic sporadic insulinoma. Endoscopy 2011;43(Suppl 2) UCTN:E328-E329.

36. Yang D, Inabnet WB 3rd, Sarpel U, DiMaio CJ. EUS-guided ethanol ablation of symptomatic pancreatic insulinomas. Gastrointest Endosc 2015;82:1127.

37. Teoh AY, Chong CC, Chan AW, Lau JY. EUS-guided alcohol injection of pancreatic neuroendocrine tumor. Gastrointest Endosc 2015;82:167.

38. Park DH, Choi JH, Oh D, et al. Endoscopic ultrasonography-guided ethanol ablation for small pancreatic neuroendocrine tumors: results of a pilot study. Clin Endosc 2015;48:158-164.

39. Paik WH, Seo DW, Dhir V, Wang HP. Safety and efficacy of EUSguided ethanol ablation for treating small solid pancreatic neoplasm. Medicine (Baltimore) 2016;95:e2538.

40. Choi JH, Park DH, Kim MH, et al. Outcomes after endoscopic ultra- 
sound-guided ethanol-lipiodol ablation of small pancreatic neuroendocrine tumors. Dig Endosc 2018;30:652-658.

41. Matsumoto K, Kato H, Kawano S, et al. Efficacy and safety of scheduled early endoscopic ultrasonography-guided ethanol reinjection for patients with pancreatic neuroendocrine tumors: Prospective pilot study. Dig Endosc 2020;32:425-430.

42. Silva FAOB, Colaiacovo R, Araki O, et al. Endoscopic ultrasoundguided fine needle injection of alcohol for ablation of an insulinoma: a well documented successful procedure. Endoscopy 2019;51:E57E58.

43. Armellini E, Crinò SF, Ballarè M, Occhipinti P. Endoscopic ultrasoundguided radiofrequency ablation of a pancreatic neuroendocrine tumor. Endoscopy. 2015;47(Suppl 1) UCTN:E600-E601.

44. Pai M, Habib N, Senturk H, et al. Endoscopic ultrasound guided radiofrequency ablation, for pancreatic cystic neoplasms and neuroendocrine tumors. World J Gastrointest Surg 2015;7:52-59.

45. Lakhtakia S, Ramchandani M, Galasso D, et al. EUS-guided radiofrequency ablation for management of pancreatic insulinoma by using a novel needle electrode (with videos). Gastrointest Endosc 2016;83:234-239.

46. Bas-Cutrina F, Bargalló D, Gornals JB. Small pancreatic insulinoma: successful endoscopic ultrasound-guided radiofrequency ablation in a single session using a 22-G fine needle. Dig Endosc 2017;29:636638.

47. Waung JA, Todd JF, Keane MG, Pereira SP. Successful management of a sporadic pancreatic insulinoma by endoscopic ultrasound-guided radiofrequency ablation. Endoscopy 2016;48(Suppl 1):E144-E145.

48. Choi JH, Seo DW, Song TJ, et al. Endoscopic ultrasound-guided radiofrequency ablation for management of benign solid pancreatic tumors. Endoscopy 2018;50:1099-1104.

49. Barthet M. Endoscopic ultrasound-guided radiofrequency ablation for pancreatic neuroendocrine tumor. Ann Endocrinol (Paris) 2019;80:182-184.

50. Kim HJ, Seo DW, Hassanuddin A, et al. EUS-guided radiofrequency ablation of the porcine pancreas. Gastrointest Endosc 2012;76:10391043. 